The Turkish Online Journal of Design, Art and Communication - TOJDAC

ISSN: 2146-5193, September 2018 Special Edition, p.1030-1036

\title{
COGNITIVE CONCEPTUALIZATION AND CATEGORIZATION OF TIME DEFINITION IN ENGLISH, FRENCH AND RUSSIAN LINGUISTICS
}

\author{
Sofya Akhmetovna MOISEEVA \\ The National Research University "Belgorod State University" (BelSU), Russia \\ Ekaterina Aleksandrovna UHNALEVA \\ The National Research University "Belgorod State University" (BelSU), Russia \\ Igor Vasilevich BOICHUK \\ The National Research University "Belgorod State University” (BelSU), Russia \\ Zhanna Anatolevna BUBYREVA \\ The National Research University "Belgorod State University" (BelSU), Russia \\ Elena Viktorovna LUKYANOVA \\ The National Research University "Belgorod State University" (BelSU), Russia
}

\begin{abstract}
Being the basic ontological category of existence, time is transcendent to a man, but man is able to represent his perceptual experience in linguistic semantics and verbalize temporal relationships. The article is devoted to the description of linguocognitive categorization and conceptualization of time by the material of English, French and Russian languages. The process of categorization is aimed at combining similar or identical units into larger categories, and the process of conceptualization is aimed at highlighting the minimum meaningful units of human experience. The multilevel structure of the concept of TIME, due to the complementary nature of the analyzed category, is also considered.
\end{abstract}

Keywords: Concept, Category, Linguistic and Cognitive Categorization, Cognitive Conceptualization, The Cognitive Approach

\section{INTRODUCTION}

Time plays a crucial role in the formation of the human worldview, it simulates the mechanism of its cognition and verbalization. Time is one of the forms of existence of the objective world, the basic component of human life and mentality, a universal category of non-linguistic reality. Understanding the category of time leads to the understanding of human existence as a whole, as it reflects the way of perception of the modern worldview by a certain ethnic group.

\section{METHODS}

The research process of the time language model is relevant and promising from the standpoint of cognitive science. The cognitive approach provides maximum flexibility and completeness of the analysis of any language material, and this brunch of knowledge is far beyond the language knowledge only. It involves the analysis of linguistic meaning relationship and the conceptual content, transmitted by a single word in the language system and in speech.

\section{MAIN PART}

The analyzed research is done within the framework of the cognitive paradigm of scientific knowledge, the linguistic representations of time and the peculiarities of its perception in the mentality in English, French and Russian. The study of time process as a lexical category is based mainly on the logical structure. At the present stage of development of cognitive linguistics, researchers confirm the idea, the lexical categorization is reflected in the lexical-semantic groups of words arising in the nomination of objects and phenomena of the world, and insist, language function in this regard is not natural, but artificial (Besedina, 2011). 
The key tokens, describing analyzed category in the considered languages, are English substantives English - time; French - temps; Russian - vremya. At the same time, the main part of the means of lexical nomination of temporal characteristics consists of nouns that have a time component in their meaning and represent a period of time. The time category can be represented by the following conceptual and thematic areas presented in Table 1.

Table 1. Conceptual and thematic areas of the TIME category

\begin{tabular}{|c|c|c|c|}
\hline $\begin{array}{l}\text { Conceptual and } \\
\text { thematic areas }\end{array}$ & English & French & Russian \\
\hline Daily cycle & $\begin{array}{l}\text { morning, noon, } \\
\text { afternoon, day evening, } \\
\text { midnight, night }\end{array}$ & $\begin{array}{l}\text { matin, midi, jour, } \\
\text { soir, minuit, nuit }\end{array}$ & $\begin{array}{l}\text { utro, polden', den', vecher, } \\
\text { polnoch', noch' }\end{array}$ \\
\hline $\begin{array}{l}\text { Calendar time } \\
\text { (weekly, monthly } \\
\text { cycles, seasons, } \\
\text { year) }\end{array}$ & $\begin{array}{c}\text { week, month, season, } \\
\text { year }\end{array}$ & $\begin{array}{l}\text { semaine, mois, } \\
\text { saison, an }\end{array}$ & $\begin{array}{c}\text { nedelya, mesyac, vremena } \\
\text { goda, god }\end{array}$ \\
\hline Duration system & $\begin{array}{l}\text { century, epoch, era, } \\
\text { age, time (times), } \\
\text { period }\end{array}$ & $\begin{array}{l}\text { siècle, époque, ère, } \\
\text { période, temps, } \\
\text { age, étape }\end{array}$ & $\begin{array}{l}\text { vek, ehpoha, gody, leta, pora, } \\
\text { vremya, vremena, period }\end{array}$ \\
\hline Short-term system & moment, instant & moment, instant; & mig, moment, mgnovenie \\
\hline $\begin{array}{l}\text { The age of the } \\
\text { person }\end{array}$ & $\begin{array}{l}\text { childhood, youth, } \\
\text { adulthood, old age }\end{array}$ & $\begin{array}{l}\text { enfance, jeunesse, } \\
\text { maturité, vieillesse }\end{array}$ & $\begin{array}{l}\text { mladenchestvo, detstvo, } \\
\text { otrochestvo, yunost }{ }^{\prime}, \text { molodost', } \\
\text { zrelost', starost }\end{array}$ \\
\hline
\end{tabular}

The peculiarity feature of the analyzed category is that TIME like a straight line is directed forward, it is linear and irreversible, it does not depend on the person and the events taking place in the world. As noted in the research by N.D. Arutyunova "a person does not have an organ specialized in the perception of time, but a person has a sense of time. It is generated by the perception of changes in the world. Its main source is space time-the change of the times of the day and seasons of the year" (Arutyunova, 1997).

Thus, the sense of time is something acquired through the perceptive abilities of a person in the process of socialization and integration into culture. According to the idea of S. A. Moiseieva, "the results of perception include information about the ontology of the world, selected usage system ideas of cognitive mechanisms of consciousness" (Moiseeva, 2006).

Language plays an important role in this process. V.V. Morkovkin considers time to be " an objective idea entirely possessing quantitative (metric) and qualitative (topological) properties. The first idea makes it possible to numerate the time, i.e. allow it to be measured. The second one gives the opportunity to talk about time as a certain entity and move to its comprehension" (Morkovkin, 1977). So, it is possible to allocate metric and non-metric time. The idea of time comprehension within the framework of the metric approach allows to reveal universal units of measurement of time intervals presented in Table 2. 
Table 2. Quantitative characteristics of time calculation units system

\begin{tabular}{|l|l|l|}
\hline English & French & Russian \\
\hline Second & Seconde & Sekunda \\
\hline Minute & Minute & Minuta \\
\hline Hour & Heure & Chas \\
\hline 24 hours (day) & vingt-quatre heures (jour) & Sutki \\
\hline Week & Semaine & Nedelya \\
\hline Month & Mois & Mesyac \\
\hline Year & An & God \\
\hline Century & Siècle & Vek \\
\hline
\end{tabular}

Analyzing the data of the Table 2, we come to the conclusion that the metric type of time includes such conceptual and thematic areas as: daily cycle and calendar time. Taking into consideration, the time intervals are measured by generally accepted standards, it is the most accurate to all reference scales system.

Lexical units with semantics of indefinite duration make up a separate independent group in the system of language time and belong to the non-metric type. This group is divided into two conditional systems: short duration and duration. The system of temporal lexemes with the meaning of short duration in English and French is represented by the following units: English - moment, instant; French - moment, instant; Russian - mig, moment, mgnovenie.

The considered segments of short duration do not have objective characteristics of duration, but are conventionally equated to a second, refer to subjective (inaccurate) indivisible units of time. In the Russian language, the standard of brevity was taken as the act of a single blinking of the eye century, which served as the appearance of verbal nouns such as: moment. Semantics of these words carries the idea of transience.

It should be noted, the ability of lexical units with short-term semantics is typical to acquire the value of indefinite or long periods. Thus, a whole fragment of life can correspond to a moment: Life is a moment between the past and the future. In contrast to metric time units, lexical units with indefinite time are more prone to such stylistic device as Metaphorization. The temporal meanings formed as a result of the mechanism of conceptual metaphor give grounds to speak about the metaphorical model of lexical conceptualization of time (Evans, 2011).

The category of TIME is developed through internal complex thought processes, in particular abstraction, correlation of objective time with internal processing and its understanding, transformation of information received from outside. The concept of TIME is a form of "reflection of real time in the human consciousness in the form of time concepts" (Konnova \& Zabotkina 2012). According to J. Lakoff, the basis of categorization and conceptualization as basic processes of knowledge is common to all people in effecting on cognitive mechanisms (Lakoff 2002). Thus, the categorical and conceptual TIME has an anthropocentric nature. According to N.D. Arutyunova, "the time factor plays a crucial role in the creation of the human model, and the human factor - in the modeling of time" (Arutyunova, 1997).

One of the properties of the category is the hierarchy, i.e. the ability to split into levels on the principle of generalization. To prove the idea of prototypical approach it was suggested that categorization should be carried out at three levels. 
The first, the highest level of generalization is called superordinate, the second-basic, assuming both the possibility of generalization at the superordinate level, and the possibility of concretization at the level, is called subordinate. As noted in the idea of N. N. Boldyrev, abstract semantics refers to the superordinate level, and words of specific semantics - to the basic or subordinate level (Boldyrev, 2014).

The importance in the prototypical theory is given to the basic level. It is this level, according to E. Roche, which is psychologically the most significant. It plays a leading role in the categorization process, it is the most "convenient" for the formation of the prototype and meets the criterion of the most typical (Croft \& Cruse, 2004).

The process of human understanding of an idea operates with the basic level, on which the perception of objects is complex, and the operation of concepts is carried out unconsciously. The vocabulary of the basic level is the most significant from the cognitive point of view, it forms the basis of the vocabulary. Levels of time lexical categorization are represented in Table 3.

Table 3. Levels of time lexical categorization

\begin{tabular}{|c|c|c|c|}
\hline $\begin{array}{c}\text { Levels of } \\
\text { categorization }\end{array}$ & English & French & Russian \\
\hline Superordinate & temporality & temporalité & temporal'nost' \\
& time & temps & vemunda \\
\hline & second & seconde & minuta \\
& minute & minute & chas \\
& hour & heure & sutki \\
& 24 hours (day) & vingt-quatre heures & nedelya \\
Base & (jour) & mesyac \\
& month & moine & god \\
& year & an & \\
& century & siècle & \\
& & & \\
& & &
\end{tabular}




\begin{tabular}{|c|c|c|c|}
\hline Superordinate & $\begin{array}{l}\text { timeout - break in } \\
\text { football; } \\
\text { medical timeout- } \\
\text { three-minute or five- } \\
\text { minute pre- } \\
\text { announced break; } \\
\text { set-break- break } \\
\text { between sets (in } \\
\text { tennis); } \\
\text { water break- water } \\
\text { break in the rules of } \\
\text { the game of } \\
\text { basketball; } \\
\text { bait time- break for } \\
\text { meal during the } \\
\text { working shift, } \\
\text { (mining); } \\
\text { midshift - break } \\
\text { between shifts } \\
\text { (mining); } \\
\text { idle hours - hours of } \\
\text { downtime at work; } \\
\text { timeout mode- break } \\
\text { in the device } \\
\text { (information } \\
\text { technology); } \\
\text { breakdown period-a } \\
\text { break in the power } \\
\text { supply }\end{array}$ & $\begin{array}{l}\text { pause - football break } \\
\text { (sports vocabulary); } \\
\text { time-out - time to relax } \\
\text { at the chess } \\
\text { championship; } \\
\text { timeout medical- } \\
\text { three-minute or five- } \\
\text { minute pre-announced } \\
\text { break; } \\
\text { set-break - break } \\
\text { between sets (in } \\
\text { tennis); } \\
\text { temps mort-easy to } \\
\text { work; a break from the } \\
\text { game; } \\
\text { suspension d'audience } \\
\text { - a break in the court } \\
\text { session; } \\
\text { intercours - break } \\
\text { between lectures; } \\
\text { pause-buffet-short } \\
\text { break for food; } \\
\text { pause thé - tea break }\end{array}$ & $\begin{array}{l}\text { taimaut - break in football; } \\
\text { meditsinskiy taimaut - three- } \\
\text { minute or five-minute pre- } \\
\text { announced break; } \\
\text { set-breyk - break between sets } \\
\text { (in tennis); } \\
\text { kofe-breyk - short break on the } \\
\text { conference; } \\
\text { peremena - break between } \\
\text { classes in educational } \\
\text { institution; } \\
\text { akademicheskiy otpusk - leave } \\
\text { provided in secondary and } \\
\text { higher educational institutions } \\
\text { for medical or other reasons }\end{array}$ \\
\hline
\end{tabular}

Analyzing the data of the Table 3, we can conclude, the superordinate level reflects generalized representations, words of broad abstract semantics: time and temporality. Basic and subordinate levels operate with a specific vocabulary of semantics. For example, the sports terminology of time-out, medical time - out, set-break involves not only a break in a certain sport (time - break in football, setbreak in tennis), but also a certain duration and rules of behavior of players. The presence of lexical universals at the superordinate and basic levels indicates the general conceptual basis of the studied languages. At the subordinate level, their national-specific features are manifested.

One must mention, the described levels of categorization existing in the human mentality do not have clearly defined boundaries and actively interact with each other. Within each level, it is possible to identify different sub-levels, which can be represented in the form of a taxonomic system associated with a specific conceptual and thematic area. It is the semantic meaning of words that determines their attitude to a particular level of categorization.

An important feature of the category is that it combines concepts and is "a grouping of units characterized by a common property - to be a representative of something outside the sign" (Kubryakova, 2004). Thus, it is the concepts that form the basis of categories. In the conceptual 
system of human beings, they can be presented as two different types of knowledge: "thematic and operational concepts reflecting its two main aspects: static and dynamic. The first ones are the units of knowledge as the main elements of the conceptual system in its static aspect. The second are mental representations of objects, events and their specific characteristics as units of knowledge (meanings), which a person operates in the process of speech activity for the purpose of knowledge or orientation transfer" (Boldyrev, 2016).

According to N.N. Boldyrev, TIME refers to the thematic type of concepts that "represent the units of knowledge as the main elements of the conceptual system in its static aspect, are thought constructs, units of theoretical knowledge, representing the entire collective experience of knowledge of the world" (Boldyrev, 2016). Their research includes an analysis of the relevant conceptual and thematic area, its structure and content. Thematic concepts are gnoseological constructs, the result of understanding of knowledge about the world, their accumulation. The study of the thematic concept of TIME involves the study of the structure and content of this category and the entire conceptual and thematic area: its elements, their characteristics and relationships, ways and levels of conceptualization and categorization of time in the scientific and everyday worldview, perhaps its philosophical, physical and linguistic understanding, i.e. all types of knowledge accumulated by mankind about this phenomenon. The analysis of the operational concept of the same name is related to the study of specific meanings, cognitive and linguistic contexts, cognitive and linguistic mechanisms of the formation of these meanings in specific language structures based on certain characteristics of the thematic concept and taking into account the specific conditions of communication and characteristics of its participants. N.N. Boldyrev noted, in each case the speech can go about the physical (time), biological (the years fly), social (stressful time), functional (storage time) of the time. For example, the individual meaning (the transfer of the corresponding operational concept to the interlocutor) of language expression is sorely short of time and depends on the specific personal idea of the author, the context of the knowledge of interlocutors, used cognitive mechanisms, a certain situation: 'a lot of things at home or at work', 'loaded with study or sports training', 'a lot of public assignments', 'constant travels and business trips', 'a lot of orders', etc. (Boldyrev, 2016).

The allocation of ontological properties of time and the classification of its species is a significant difficulty, since TIME belongs to the most complex and multifaceted categories of reality. Topological properties of time describe its continuity, one-dimensionality and irreversibility. They seem to be the most universal and therefore applicable in linguistic research, because they allow to reveal the essence of language time on the basis of General universal ontological properties.

\section{CONCLUSION}

Thus, we can conclude, the concept of English - time / French - temps / Russian - vremya is a concept that organizes the structure of the mental category of TIME. It has a multi-layered organization. Its social nature determines the general cultural, intercultural and social significance, as well as national and cultural specificity, inextricably linked with the linguistic side of this concept, and manifested in the linguistic refraction. The analyzed concept is intercultural and cross-linguistic, it has universal characteristics, both in terms of content and in terms of language objectification. Its universal conceptual characteristics are due to the fact, the phenomenon of time is a universal category of human mentality. The complementarity of the analyzed concept is due to the complex system of conceptual connections and requires the use of a variety of linguistic means of representation of the necessary temporal meanings, the basis of which is not fixed in conceptual characteristics presented in the system meaning of the word. The comparative analysis of lexical temporality means in English, French and Russian languages shows both similarities and differences in the ways of expression of the universal category of TIME. Language and linguistic-cultural systems of different ethnic groups differ significantly from each other, but it is a common fact that there are semantic and lexical universals, indicating the general conceptual basis on which human language, thinking and culture are built.

\section{REFERENCES}

Arutyunova N.D. (1997). Vremya: modeli i metafory. Yazyk i vremya [Time: models and metaphors. Language and time]. Moscow: Indrik.

Besedina N.A. (2011). Modelirovanie vzaimodeystviya kognitivnykh i yazykovykh struktur (na primere morfologicheskoy reprezentatsii $v$ yazyke) [Modeling the interaction of cognitive and linguistic structures (by the example of morphological representation in the language)]. In: Kognitivnye 
issledovaniya yazyka. Vyp. IX. Vzaimodeystvie kognitivnykh i yazykovykh struktur: sb. nauch. tr. Moscow: IYaz RAN.

Boldyrev N.N. (2014). Kognitivnaya semantika. Vvedenie v kognitivnuyu lingvistiku [Cognitive semantics. Introduction to Cognitive Linguistics]. Tambov: Izdatel'skiy dom TGU im. G.R. Derzhavina, 4.

Boldyrev N.N. (2016). Tipologiya kontseptov i yazykovaya interpretatsiya [Typology of concepts and language interpretation]. In: Novaya Rossiya: traditsii $i$ innovatsii v yazyke $i$ nauke o yazyke: materialy dokladov $i$ soobshcheniy Mezhdunarodnoy nauchnoy konferentsii, posvyashchennoy yubileyu Zasluzhennogo deyatelya nauki RF, doktora filologicheskikh nauk, professora L.G. Babenko, 28 -30 sent. 2016 g., Ekaterinburg.

Croft W. \& Cruse A.D. (2004). Cognitive Linguistics. New York: Cambridge University Press.

Evans V. (2011). Temporal Frames of Reference. Book of Abstracts. The Third Conference of the Scandinavian Association for Language and Cognition SALC III. Copenhagen, June 14-16th, 2011.

Konnova M.N. \& Zabotkina V.I. (2012). Kontseptual'noe i yazykovoe vremya [Conceptual and linguistic time]. In: Rossiya: izmenyayushchiysya obraz vremeni skvoz' prizmu yazyka. Reprezentatsiya kontsepta vremeni $v$ russkom yazyke $v$ sopostavlenii $s$ angliyskim $i$ nemetskim yazykami. Moscow: Rukopisnye pamyatniki drevney Rusi.

Kubryakova E.S. (2004). Yazyk i znanie: Na puti polucheniya znaniy o yazyke: Chasti rechi s kognitivnoy tochki zreniya. Rol' yazyka v poznanii mira [Language and knowledge: On the way of getting knowledge of the language: Parts of speech from the cognitive point of view. The role of language in the knowledge of the world]. In-t yazykoznaniya RAN. Moscow: Yazyki slavyanskoy kul'tury.

Lakoff G. (2002). The Contemporary Theory of Metaphor. Metaphor and Thought. Cambridge University Press.

Moiseeva S.A. (2006). Semanticheskoe pole glagolov vospriyatiya v zapadno-romanskikh yazykakh: monografiya [Semantic field of verbs of perception in Western Romance languages: monograph]. Belgorod: Izd-vo BelGU.

Morkovkin V.V. (1977). Opyt ideograficheskogo opisaniya leksiki (analiz slov so znacheniem vremeni v russkom yazyke). Moscow: Izd-vo Mosk. un-ta. 